
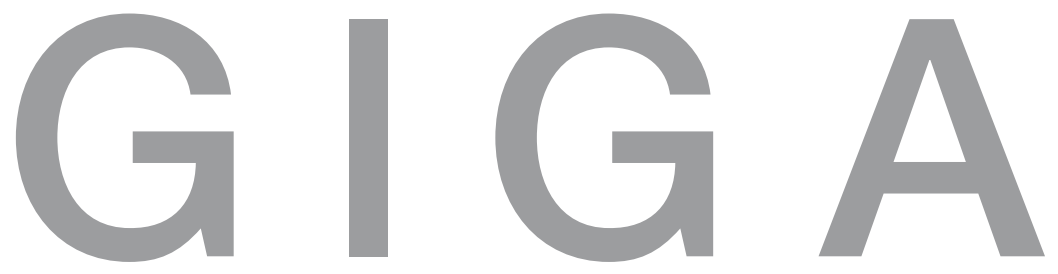

Working

German

Institute of Global and Area Studies Papers

Leibniz-Institut für Globale und Regionale Studien

GIGA Research Programme:

Legitimacy and Efficiency of Political Systems

How Does Neopatrimonialism Affect the African State?

The Case of Tax Collection in Zambia

Christian von Soest 


\section{GIGA Working Papers}

Edited by GIGA German Institute of Global and Area Studies / Leibniz-Institut für Globale und Regionale Studien.

The Working Paper Series serves to disseminate the research results of work in progress prior to publication to encourage the exchange of ideas and academic debate. An objective of the series is to get the findings out quickly, even if the presentations are less than fully polished. Inclusion of a paper in the Working Paper Series does not constitute publication and should not limit publication in any other venue. Copyright remains with the authors. When Working Papers are eventually accepted by or published in a journal or book, the correct citation reference and, if possible, the corresponding link will then be included in the Working Papers website at:

www.giga-hamburg.de/workingpapers.

GIGA research unit responsible for this issue: Research Programme 'Legitimacy and Efficiency of Political Systems'.

Editor of the GIGA Working Paper Series: Bert Hoffmann <hoffmann@giga-hamburg.de> Copyright for this issue: (C) Christian von Soest

Editorial assistant and production: Verena Kohler and Vera Rathje

All GIGA Working Papers are available online and free of charge at the website: www.giga-hamburg.de/workingpapers. Working Papers can also be ordered in print. For production and mailing a cover fee of $€ 5$ is charged. For orders or any requests please contact:

E-mail: workingpapers@giga-hamburg.de

Phone: ++49 (0)40 - 42825548

GIGA German Institute of Global and Area Studies /

Leibniz-Institut für Globale und Regionale Studien

Neuer Jungfernstieg 21

20354 Hamburg

Germany

E-mail: info@giga-hamburg.de

Website: www.giga-hamburg.de 


\title{
How Does Neopatrimonialism Affect the African State? The Case of Tax Collection in Zambia
}

\begin{abstract}
Following the neopatrimonialism paradigm, it can be hypothesised that in African states informal politics of the rulers infringe on the collection of taxes and in turn reduce state revenues. This article tests this proposition for the case of Zambia. The main finding is that there is no linear correlation between a neopatrimonial system and the collection of taxes. Neopatrimonial continuity in the country is evidenced by three factors; the concentration of political power, the award of personal favours and the misuse of state resources. Despite this continuity, the revenue performance has increased considerably with the creation of the semi-autonomous Zambia Revenue Authority. This demonstrates that the effect of neopatrimonialism on public policy in the African state is highly context-specific and dependent on the interaction with additional variables. Donor pressure has been the most important in the Zambian case. In order to apply neopatrimonialism for further empirical work on public policy in the African state, these additional variables have to be incorporated into the analysis.
\end{abstract}

Key words: Neopatrimonialism, collection of revenue, tax systems, Zambia, African state, donors

\section{Christian von Soest,}

is Political Scientist and Research Fellow at the GIGA Institute for African Affairs in Hamburg, Germany.

Contact: soest@giga-hamburg.de, website: http://staff.giga-hamburg.de/soest 


\section{Zusammenfassung}

Wie beeinflusst Neopatrimonialismus den afrikanischen Staat? Die Steuererhebung in Zambia

Ausgehend vom Konzept des Neopatrimonialismus kann vermutet werden, dass in afrikanischen Staaten informelle Politiken der Herrscher die Erhebung von Steuern beeinträchtigen und damit die Einnahmen des Staates vermindern. Der vorliegende Artikel testet diese Hypothese am Beispiel von Zambia. Das Hauptergebnis ist, dass kein linearer Zusammenhang zwischen einem neopatrimonialen System und dem Erheben von Steuern besteht. Trotz neopatrimonialer Kontinuität, nachgewiesen durch die drei Variablen Konzentration politischer Macht, Verteilen persönlicher Gefälligkeiten und Missbrauch von staatlichen Ressourcen, hat die Schaffung der halb unabhängigen Zambia Revenue Authority zu einer beträchtlichen Steigerung der staatlichen Einnahmen geführt. Dies zeigt, dass der Effekt von Neopatrimonialismus auf bestimmte Politikfelder des afrikanischen Staates in höchstem Maße Kontext-spezifisch und abhängig von zusätzlichen Variablen ist. Die wichtigste im zambischen Fall ist der Einfluss von Gebern. Um Neopatrimonialismus für die empirische Arbeit zu public policy in afrikanischen Staaten anzuwenden, müssen diese zusätzlichen Variablen in der Analyse berücksichtigt werden. 


\title{
How Does Neopatrimonialism Affect the African State? The Case of Tax Collection in Zambia
}

\author{
Christian von Soest ${ }^{1}$
}

\section{Article Outline}

1. Introduction

2. Conceptualising Neopatrimonialism

3. Neopatrimonialism in Zambia

4. Neopatrimonialism and the Collection of Revenue

5. Conclusion

\section{Introduction}

Proponents of the concept of neopatrimonialism assert that distinct features distinguish governance in the African state from its counterparts in other world regions (Médard 1982; Bratton/van de Walle 1997; Chabal/Daloz 1999; Englebert 2000; van de Walle 2001b). The particular nature of the African state, characterised by the lack of separation between the public and the private sphere, is found as fundamentally inhibiting state capability on the continent.

1 The empirical results presented in this article emanate from the author's PhD on 'The African State and the Capability to Raise Revenue. A Comparative Study on the Tax Administration in Zambia and Botswana', submitted to the University of Leipzig. The author is indebted to Ulf Engel, Matthias Basedau and Gero Erdmann, who all provided invaluable support and advice to his research project. Field work was financed by a scholarship from the German Academic Exchange Service (DAAD). 
The inability to collect taxes², which commonly form the financial basis for all other state functions (e.g. internal and external security, public welfare), is one of the most fundamental deficits in this respect (van de Walle 2001b: 182-183; Bräutigam 2002: 14; Olowu 2003: 105). An IMF study (1997: 6-7) found that in some African countries more than $60 \%$ of the tax potential remains untapped. As a consequence, hardly any of the African states is financially self-sufficient. The continent today is the most donor-dependent region in the world (World Bank Africa Database 2005). The perspective of neopatrimonialism implies that this cannot only be attributed to Africa's low socio-economic status, but also to political interference with the process of collecting state revenues. It is this premise this article will test in respect to Zambia, a country whose political practice - similar to other African states - is assumed to be characterised by neopatrimonialism. ${ }^{3}$

Since colonial times, Zambia's state finances have been based on the extraction of copper. The sharp decline of world market prices for the mineral resource in the mid-1970s caused a severe revenue and economic crisis. In 2000 real GDP per capita had declined to only about 55\% of its 1975 level (World Bank 2003: 112). Up to the 2005 Heavily Indebted Poor Countries (HIPC) debt relief, Zambia had been one of the most-heavily indebted countries in subSaharan Africa (IMF 2005a). Despite the need for new sources of state income, the singleparty government of President Kaunda refrained from strengthening domestic tax collection.

Only after the reintroduction of the multi-party system in 1991 and the electoral success of the Movement for Multi-Party Democracy (MMD), the new government radically strengthened domestic revenue generation. Yet, the indicators show that Zambia's political elite has resorted to neopatrimonial practices largely unabatedly. The country therefore constitutes a particular interesting case study for analysing neopatrimonialism and its effects on the collection of state revenue.

Empirically, over 75 qualitative interviews conducted in Zambia allow for 'process tracing' and provide most of this study's empirical value added. Six respondent groups from inside as well as outside the tax administration were interviewed. ${ }^{4}$ The respondents were tax officers from a) the management and from b) middle/low hierarchy levels, business persons, civil society representatives, politicians and political decision makers, social scientists and employees from international organisations. In addition, primary sources such as the tax administration's annual reports and the budget speeches were systematically analysed.

2 In this article, the terms 'taxes' or 'revenue' encompass income taxes, value-added taxes and customs duties.

3 Posner and Simon (2002: 331) portray Zambia as a 'modal case' in the African context.

4 Field work was conducted from 4 March to 27 May 2004. Research permission granted by the Zambia Revenue Authority is greatly acknowledged. 
The article starts by conceptualising the main facets of neopatrimonialism. It then sets out to operationalise and analyse neopatrimonialism in Zambia with the indicators introduced. In the third step the article assesses the effects of neopatrimonialism on the collection of revenue. The main finding is that the relationship between neopatrimonialism and central tax collection is highly context-specific and dependent upon the specific interaction with other variables. As will be outlined in the conclusion, there is need to also take into account these intervening variables, in this case particularly donor influence, in order to apply neopatrimonialism for analysing political practice in the African state.

\section{Conceptualising Neopatrimonialism}

Neopatrimonialism is a 'universal concept' which its proponents perceive to have particular value for explaining Africa's state weaknesses, democratic deficiencies and economic crisis. Bratton and van de Walle (1997: 277) for instance maintain that the distinctive institutional hallmark of African regimes is neopatrimonialism'. The basic proposition of the heuristic concept is that informal, particularistic politics of the rulers pervade formal state institutions. The separation between the public and the private realm, which stands at the basis of the 'modern' conception of the state, is abrogated. ${ }^{5}$

Principally, the term neopatrimonialism denotes the simultaneous operation of the two Weberian ideal types of patrimonial and rational-legal domination (Clapham 1985: 48; Bratton/van de Walle 1997: 62). Patrimonialism connotes that a patron in a certain social and political order bestows gifts from own resources on followers in order to secure their loyalty and support (Weber 1980 [1922]: 133-134, 136). Clients, in turn, obtain material benefits and protection. In a neopatrimonial system, patrons typically are office-holders in state institutions who misuse public funds or office in order to stay in power. Social practice as a result is fundamentally different compared to the impersonal formal rules which are supposed to guide official action (Erdmann/Engel 2006: 18; Alence 2004: 165).

Taking the case of tax collection, it can be hypothesised that neopatrimonialism leads to political interference ${ }^{6}$ with the tax administration and in turn reduces state revenue. Donors as well as scientists regard these organisations as focal points of interference from the political sphere (World Bank 2002: 111; Gill 2003: 1; Rose-Ackerman 2004: 28). Two prime ways of undue influence from the political sphere are possible: First, the placement of unqualified top-, middle- and low-level tax officers, which fill patronage positions. Second, neopatrimo-

5 For an extensive discussion of the neopatrimonialism concept see Erdmann/Engel (2006).

6 This article understands every policy or political action which violates the rational-legal logic of the tax administration and the administrative chain of command as 'interference'. 
nial interference with the tax administration's day-to-day business in order to prevent audits at businesses that enjoy political protection, to inhibit controls at border posts and to harass opponents of the neopatrimonial 'big man'. Both strategies serve the political interest of securing authority and the private interest of reducing tax payments. They keep the tax administration weak and in turn significantly reduce the room for self-sufficiently financing the African state.

Reading the vast array of literature on neopatrimonialism in sub-Saharan Africa, it is striking that widely accepted indicators for this political practice are inexistent and that systematic analyses of its effects on public policy are rare (one exception is Kjaer 2004). The key methodological aim of this article therefore is to contribute to the systematic operationalisation of the concept. In accordance to Bratton and van de Walle (1997: 63-68), it applies the three features 'systematic concentration of political power', 'award of personal favours' and 'use of state resources for political legitimation' for assessing the neopatrimonial profile of Zambia. Such analysis provides strong indications about the character of the Zambian state and will reveal the strong continuity of neopatrimonial practices in the country.

\section{Neopatrimonialism in Zambia}

Since independence, Zambia's rulers have consistently applied all three features of neopatrimonial politics.

\section{Concentration of Political Power}

The first facet, the systematic concentration of political power, implies the dominance of one individual, 'who resists delegating all but the most trivial decision-making tasks' (Bratton/ van de Walle 1997: 63). ${ }^{7}$ As a defining feature of this 'big man politics', the president or, in other words, the patron, stays in power for a long time, sometimes until the end of his life. Indeed, presidents in sub-Saharan Africa on average officiate significantly longer than their counterparts in Asia and Latin America (Bienen/van de Walle 1992: 693). Young speaks of “"life president" power management' (1994: preface on x). On the other hand, neopatrimonial rulers frequently rotate the political elite in order to prevent any potential opponent from developing his or her own power base and also in order to extend the clientelist net-

\footnotetext{
Bratton and van de Walle term this feature 'presidentialism'. However, this is misleading as the traditional political science definition of presidentialism refers to political systems in which the president is directly elected by the electorate, exerts the executive power and cannot be deselected by parliament (in contrast to parliamentary systems). This article therefore refers to the phenomenon in question as 'concentration of political power'.
} 
work (Snyder/Mahoney 1999: 108-109; Snyder 1992: 392). The simultaneous fulfilment of both requirements, a long tenure of presidents and a short tenure of key government members, therefore suggests a neopatrimonial power concentration.

This has exactly been the case in Zambia. With Kenneth Kaunda, Frederick Chiluba and Levy Mwanawasa, the country has only seen three Presidents since independence in 1964. Their average length of tenure amounts to 14 years 8 , which stands above the 11.6 years African state leaders have on average managed to stay in power from 1980 to 2005 (van de Walle 2005: 74).

The first President Kaunda served for 27 years in office and entrenched his power with a corps of personal advisors which in turn reduced the influence of the cabinet and other units of the ruling United National Independence Party (UNIP). He not only gained from particular legitimacy as Zambia's founding President who had led the struggle for independence but also augmented his control of the political process by promulgating the one-party state in December 1972 (Tordoff/Molteno 1974: 252; Scott 1980: 152).

The neopatrimonial centralisation of power in Zambia also finds expression in the frequent change of ministers. The average tenure of key ministers from independence until today stands at only 2.4 years. ${ }^{9}$ Consequently, the most important cabinet members have exercised their functions for only half of a legislative period on average. This pattern of 'elite circulation' (Burnell 2001b: 241) has shown a high degree of consistency and has endured during Zambia's one-party Second Republic (from end of 1972 to 1991) and during the multi-party Third Republic (since November 1991).

In a major cabinet reshuffle in April 1993 for instance, President Chiluba removed those reform-minded ministers he perceived to be a threat to his rule from office. Others were frustrated to the extent that they resigned from government (Erdmann/Simutanyi 2003: 14). With an average tenure of less than two years, the 'ministerial game of musical chairs'

8 Article 35 (2) of the 1991/1996 Constitution (Republic of Zambia 2004) restricts the tenure of office of the President to the maximum of two five-year terms. Hence, in Zambia's multi-party 'Third Republic' the President is eligible to one re-election only. This term limit became contested in 2000 when some quarters in the ruling party MMD - apparently backed by the President - tried to amend the constitution in order to allow for a third term of President Chiluba. Only after massive public protests was this exercise stopped (Rakner/Svåsand 2005: 97; Rakner 2003: 114). These manoeuvres strengthen the case being made in this article of a neopatrimonial power concentration in Zambia.

9 Key ministers include the Vice-President/Prime Minister and the Ministers of Finance, Foreign Affairs, Defence and Interior. Under President Kaunda, the average tenure was 2.4 years, under President Chiluba 2.7 years and under President Mwanawasa (up to the year 2005) 1.6 years. Due to the comparatively short endurance of the Mwanawasa Presidency, the figures give only first indications about big man rule trends in his administration. Sources: 1964-1969: The Statesman's Year-Book (Macmillan 1964-1970), 1970-2005: Africa South of the Sahara (Europa Publications 1971-2004; Routledge 2005). 
(Tordoff/Molteno 1974: 254) in the key departments has not slowed down under the current President Mwanawasa who was re-elected on 28 September 2006 (Electoral Commission of Zambia 2006). In sum, the neopatrimonial concentration of political power has been a feature consistently applied in Zambian politics.

\section{Award of Personal Favours}

Not only do Zambia's Presidents frequently rotate ministers, they also award personal favours to other elite members in order to secure their rule. A prime means has been the expansion of the ministerial cabinet, which features prominently for awarding personal favours in Africa (van de Walle 2001a: 32-33). The Zambian cabinet has grown significantly over the years; from 14 ministers in 1964 to currently 23 members. ${ }^{10}$ This is congruent with the trend in many African countries. Van de Walle shows that the average number of cabinet ministers in the region rose from 20.1 members in 1979 to 24.6 in 2000 (2005: 80). ${ }^{11}$ As in Zambia, these cabinet sizes cannot be substantiated with functional necessities. Most developed countries, having much larger populations and economies, are governed by cabinets of only 15 to 20 ministers (OECD 2004: 2).

The number of core cabinet ministers only moderately reflects the real enlargement of patronage posts in the Zambian government. In 1968, President Kaunda appointed ministers for each of Zambia's nine provinces. After the introduction of the one-party state, the UNIP Central Committee became a parallel structure to the ministerial cabinet (van Donge 1995: 196). The President also created additional posts in order to pursue his policy of 'tribal balancing' in Zambia's multi-ethnic society (Carey 2002: 60). Despite Zambia's severe and enduring economic crisis, originally caused by the sharply decreasing world-market prices of copper in the mid-1970s, the ministerial cabinet went up to a peak of 27 ministers (1986 to 1988) during the Second Republic. Furthermore, the 'UNIP patronage machine' (Bratton 1994: 104) massively expanded public sector employment. Following Bates and Collier (1993: 391), in 1985, the party filled over 40,000 public offices in Zambia's capital Lusaka alone.

After the transition from the one-party state to multi-party rule and the formation of his Movement for Multiparty Democracy (MMD) government in 1991, President Chiluba, also

10 Totals include Presidents and Vice-Presidents, but not Deputy Ministers, Permanent Secretaries and Provincial Governors. The data on Cabinet size were mostly derived from the months August and September of the respective years. Sources: 1964-1969: The Statesman's Year-Book (Macmillan 1964-1970), 1970-2005: Africa South of the Sahara (Europa Publications 1971-2004; Routledge 2005).

11 In assessing the average number of Cabinet members for sub-Saharan Africa, van de Walle systematically excluded 'Heads of States'. For comparability to this article's figures one post was added to his average data, respectively. 
formed a large cabinet. He appointed 25 ministers to the Third Republic's first cabinet; a number which rose to an all-time high of 28 posts one year later. Even today the bloated government is a feature of Zambian politics. A 2004 media campaign to reduce the number of high-level government posts has remained unsuccessful (The Post 20.4.2004; The Post 26.4.2004). According to a Government of Zambia document, the total number of government members (President, Vice-President, Ministers and Vice-Ministers) on 3 August 2005 stood at 67 (Republic of Zambia 2005). In essence, this consistent use of the cabinet as a key locus for awarding personal favours by the 'big men' augments the argument for the dominance of neopatrimonial practices in Zambian politics.

\section{Misuse of State Resources}

The misuse of state resources ${ }^{12}$, the third feature of neopatrimonialism, has also characterized Zambia's political practice. It can be assessed through the existence of special funds over which only the big man has discretion. The Corruption Perception Index (CPI) and the similar World Bank Governance Index in respect to 'control of corruption' provide further evidence. Both are composite indices which incorporate various studies on a country's perceived incidence of corruption (Graf Lambsdorff 2005; Kaufmann et al. 2005a). Similar to other research, this article uses the existence of serious corruption levels as an indicator for the neopatrimonial misuse of state resources (Manow 2002: 24-25; Basedau 2003: 281-287).

During the Second Republic, a Leadership Code obliged all cabinet and Central Committee members to separate public office and private interests (Kaunda 1972, par. 4). Yet, the text of the code was not put into practice. A general pattern emerged of misusing public functions and resources. ${ }^{13}$ It became apparent that 'bribes and favours offered a host of rewards for "gatekeeping' services"' (Szeftel 2000: 210). Monitoring institutions such as the AntiCorruption Commission remained toothless and the infrequent exposure of government malpractices did not counter the systematic misappropriation of public resources (Afronet 2002: 89; van Donge 1995: 198; Tordoff/Molteno 1974: 287).

President Chiluba's government also misused state resources, often to the advantage of the ruling party MMD (Erdmann/Simutanyi 2003: 72; Szeftel 2000: 217). ${ }^{14}$ According to Trans-

12 Bratton and van de Walle term this facet 'use of state resources for political legitimation'. However, in all political systems governments 'use' state resources for securing their acceptance. The key difference is how and for what projects public resources are spent. This article therefore refers to the phenomenon in question as 'misuse of state resources'.

13 Well-researched examples can be found in Szeftel (1982; 2000) and Bratton/Posner (1999: 393-398).

14 In addition to the general problem of sources, it is difficult to precisely compare the misuse of state resources between the Kaunda and the Chiluba administrations as these instances of neopatrimonial politics have been more easily uncovered in the multi-party Third Republic which allows for 
parency International Zambia (TIZ), a number of ministers were involved in corruption scandals without being dismissed (TIZ 2002: 35-37; TIZ 2003: 9-10, 13). Furthermore, Zambia has from 1998 to 2005 received low scores on Transparency International's CPI. The country always ranked in the worse half, for most of the time in the worst third of countries included in the index (Internet Center for Corruption Research 2005). Zambia's 'control of corruption' marks in the World Bank Governance Index have equally been low. The country has consistently featured among the third of countries perceived to be most corrupt (Kaufmann et al. 2005b).

A similar 'blurring of the line' between the governing party and the state took place as in the Second Republic (Rakner/Svåsand 2005: 95). Before the 1996 elections, the government sold council houses to tenants at favourable conditions. Commentators largely perceived this move as an inducement to vote for the MMD (Financial Mail 27.8.-2.9.2002; Bratton/Posner 1999: 397). In 1999, the government created a 'Presidential Discretionary Fund', unofficially called 'Slush Fund', to distribute favours to clients. The fund's reserved budgetary allocations of around 12 billion Kwacha per annum (roughly US\$ 5 million at that time), were at the disposal of the President alone, who apparently deployed it for partisan purposes (Burnell 2001b: 251; Simon 2005: 209). ${ }^{15}$

In the face of these developments, President Mwanawasa began his tenure on 2 January 2002 by declaring his administration to be 'a government of laws not of men'. One of the centrepieces of his 'new deal' government was the proclaimed fight against corruption (Erdmann/ Simutanyi 2003: 78; Simon 2005: 212). He lifted the immunity of former President Chiluba and charged him and some of his allies with abuse of office. However, there are strong indications that President Mwanawasa's campaign has remained inconsequential and is primarily used as a way of silencing his opponents (TIZ 2002: 30; EIU 2005: 16). The misuse of state resources has remained a recurrent feature of Zambian politics.

On balance, political practice in Zambia since independence in 1964 has been characterised by neopatrimonialism. Due to its inherent lack of accountability, the single-party state in the Second Republic seems to have reinforced the neopatrimonial impulse (Bratton 1994: 125). Yet, it is striking to see the neopatrimonial continuity throughout the Third Republic after the abolition of single-party rule. This deeply ingrained system of neopatrimonialism has created a hostile environment for a rational-legal tax administration and the collection of

stronger civil society, media and donor oversight than the Second Republic. The common perception that misuse of state resources was more rampant under President Chiluba's rule might therefore been an artefact caused by the different quality of sources.

15 See also Burnell's (2001a) analysis of the 'financial indiscipline' of the Chiluba government and the Transparency International Zambia report (TIZ 2003) on the abuse of public funds. Further instances are presented in Rakner/Svåsand (2005: 93-96). 
revenue. The question now to be answered is how this neopatrimonial system has affected the revenue-generating function of the Zambian state.

\section{Neopatrimonialism and the Collection of Revenue}

The institutional development of Zambia's tax administration is characterised by two phases: The first lasted from independence in 1964 to 1994, when the Departments of Taxes and of Customs and Excise were integral parts of the state structure. The second began on 1 April 1994, when the government launched the Zambia Revenue Authority (ZRA). With this semi-autonomous agency, it outsourced the collection of revenue from the traditional, stateintegrated public administration under the direct control of the Ministry of Finance. In accordance to the discussion of neopatrimonialism above, this article uses two indicators for analysing the effect of Zambia's neopatrimonial system on the tax administration: (a) merit orientation of staff and (b) political interventions with the day-to-day administrative work. This is followed by the assessment of the tax administration's revenue performance. The indicators will reveal completely different effects of neopatrimonialism on the two institutional dispensations.

\section{Zambia's Tax Administration As Part of the State Structure}

After independence, the Zambian government faced the objective need to enlarge and strengthen the inadequate tax administration apparatus inherited from colonial rule. In its first report, the Department of Taxes noted that the government had authorised 141 posts from which 127 were filled. The Department dealt with only 6,493 taxpayers at that time (DTZ 1969: 8). In accordance to the rest of the civil service, President Kaunda's UNIP government massively expanded the Departments of Taxes and of Customs and Excise. The number of staff of the Department of Customs and Excise for instance quickly rose from 280 in the year 1964 to 629 in 1967 (DCEZ 1966: 1).

However, available evidence paints the picture of an increasingly ailing administration. With the introduction of the one-party state in December 1972, Zambia's administrative structure lost most of its operational autonomy and had to predominately follow a political logic. Goldsmith (1999: 544) regards this as a general pattern for sub-Saharan Africa: 'Political interference and low standards set the wrong tone at the beginning and interacted later with poor working conditions and low pay in a classic vicious circle.'

Political and neopatrimonial considerations significantly reduced the merit orientation of Zambian tax officers. In 1968, two years after independence, a Zambian took over the post of 
the Controller of Customs and Excise from a British administrator, with the Department of Taxes following two years later. The heads of both Departments were appointees with connections to the ruling party UNIP. According to a long-serving tax officer, this form of selecting the tax administration's leadership was widely resented among tax officers. They saw the managers as unqualified 'outsiders' (14.4.2004, int.). Although technical qualifications were not completely disregarded as a recruitment criterion, the apparently best-suited candidates did not fill the tax administration's leadership positions. ${ }^{16}$

Working for the tax administration was very unattractive as the salary levels were low and the employment conditions poor. By 1991, the real remuneration for most public sector groups had declined to only 11-22\% of its 1975 value (World Bank 2003: 114). The fundamental reason could be found in Zambia's severe economic and fiscal crisis, which restricted the state's ability to remunerate its numerous civil servants properly. A second reason was that, as in many African countries, high inflation rates eroded more than $80 \%$ of the purchasing power of civil servants (van de Walle 2005: 78). According to an annual report from the Department of Taxes, trained tax officers 'tend to leave for greener pastures largely because they can be much better remunerated elsewhere or they stand better chances of promotion in other Government organs and hence get higher pay' (DTZ 1987: 9).

The recruitment, promotion and remuneration policies of Zambia's tax administration deviated considerably from the Weberian concept of public administration. This deficient merit orientation of tax administration managers and tax officers shows that Zambia's pressing need for new sources of revenue did not translate into the government strengthening the tax administration and increasingly collecting taxes from citizens and companies.

The logic of neopatrimonialism was also felt in the day-to-day business of doing tax assessments and evaluating customs duties. According to a former tax officer, 'some people had better treatment, the big shots. It depended on who you are' (14.4.2004, int.). This assertion is also valid for the Department of Customs and Excise. In his 1979 annual report, the Head of the Department openly articulated his frustration: 'The number of senior people in the Party and its Government who apparently feel they have immunity to Customs formalities continued to soar [...] Officers are now working under constant fear of being victimised if they stumble across these officials' (DCEZ 1983: 6). The regular occurrence of these interventions was confirmed by nearly all of the 75 respondents, i.e. tax officers, business persons, civil society representatives, policy makers, social scientists and employees from international

16 This mix of partly adhering to qualifications in a rational-legal sense and of patrimonial and political logics involved in filling management positions gives evidence for the existence neopatrimonialism understood as the simultaneous operation of a patrimonial and rational-legal logic in the tax administration (see definition at the beginning of the article). 
organisations, who were interviewed for this study and who had knowledge on Zambia's old, state-integrated tax administration.

This neopatrimonial interference exerted strong effects on the tax administration's revenue performance. In the beginning of the 1970s, tax revenue amounted to about $30 \%$ of GDP, a value that was predominately caused by the high copper price on the world markets (Coopers \& Lybrand 1992: par. 1). Since 1975, however, it more than halved and in 1993, the year before the introduction of the semi-autonomous Zambia Revenue Authority (ZRA), it amounted to only 15.3\% (World Bank 2003: 15).

This could not only be attributed to Zambia's economic crisis. A significant proportion of the potential tax take remained uncollected. In 1992, the Minister of Finance stated that the tax administration only tapped on one third of formal sector incomes (Republic of Zambia 1992: 19). The Department of Taxes never managed to significantly broaden the tax base and the government refrained from capturing 'difficult' taxpayer groups with intimate connections to the ruling elite. Self-employed individuals such as physicians and lawyers remained largely outside the tax net (DTZ 1976: 4).

Drawing on international aid was less 'costly' for the UNIP government than taxing its citizens. From 1975 to the present day, Zambia has received large amounts of foreign donor assistance, both in absolute terms and relative to its GDP. Up to 2001, donors in toto provided more than US\$ 12 billion of financial assistance to Zambia which was equivalent to almost 20\% of GDP (World Bank Africa Database 2005; McPherson 2004b: 446).

In April 2005, the IMF and the World Bank under their initiative for Heavily Indebted Poor Countries (HIPC) formally endorsed a US\$ 3.9 billion debt relief for Zambia (IMF 2005a). Following the June 2005 commitment of developed countries to write off bilateral debt, the Minister of Finance and National Planning expected Zambia's foreign debt to decline to US\$ 300-500 million by May 2006 (The Post 3.1.2006). However, despite strong dependence on external financing, structural conditions attached to loans were not implemented. During the two decades of one-party rule, the UNIP government failed to meet the conditions of seven formal adjustment programmes negotiated with international donors (McPherson 2004a: 31).

Neopatrimonial interference with the recruitment of staff and with the day-to-day operations were major factors causing the deficits of Zambia's tax administration during the Second Republic. Despite President Kaunda's statements to the contrary, not every citizen, i.e. taxpayer, was treated equally. Neopatrimonialism directly trickled down to the tax administration and reduced its performance. As a result, the weak revenue collection authorities inherited from colonial rule, became largely dysfunctional during the Second Republic. 


\section{Reform amidst Zambia's Neopatrimonial Environment}

The effect of neopatrimonialism on the tax collection completely changed after the regime transition in late 1991. The newly-elected MMD government not only swiftly liberalised Zambia's fiscal and economic policy (e.g. Rakner 2003; Craig 2001) but also negotiated new loan agreements with the donor community. In the face of the experiences in the 1980s, the IMF on its part added the strengthening of internal revenue collection to its conditionalities for the provision of new loans (Hill 2004: 141; Gloppen/Rakner 2002: 32). This proved to be of crucial importance, as the route of de facto unconditionally financing the state through external funds was now closed. Reform of the tax collection was inevitable for the strengthening of both internal and external state revenues.

In 1992, the British government funded initial studies, which recommended the establishment of a semi-autonomous revenue authority (Coopers \& Lybrand 1992; Gray et al. 2001). ${ }^{17}$ The arguments for taking the revenue generation out of Zambia's core state structure were two-fold. The first was to increase revenue performance through the business-like collection of taxes (see in general Devas et al. 2001). The second reason was to insulate the tax administration from Zambia's neopatrimonial environment, i.e. from political interference (Tax Policy Task Force 1992: 4).

The Zambia Revenue Authority (ZRA), replacing the ministerial Departments of Taxes and Customs and Excise started to operate on 1 April 1994. Its executive Commissioner General is appointed by the Zambian President and alone is responsible for the collection of revenue. He or she reports to a nine-member Governing Board and not to the Ministry of Finance and National Planning (Republic of Zambia 1996: sec. 10 (1), (3)).

The creation of the ZRA not only was a precondition for further donor support but was also in the interest of the new Zambian government. The revenue authority, as other institutional innovations created in the 'honeymoon period' of the Chiluba government, acted as a forceful symbol of its commitment to turn Zambia's public administration around. The addressees of this visible 'reform barometer' were both the Zambian population and the donor community. ${ }^{18}$ As will be shown, this institutional restructuring has reduced the effect of neopatrimonialism on the collection of revenue in Zambia but at the same time has been consistent with a neopatrimonial rationale.

17 The conceptual impetus was provided by the paradigm of New Public Management which promotes the creation of semi-autonomous agencies and the application of business-sector principles such as performance-related salaries for the public administration (Hood 1990). The worldwide diffusion of New Public Management has been of increasing relevance to the African state. Today, at least eight revenue authorities can be found in sub-Saharan Africa (Devas et al. 2001: 213).

18 For a general analysis of the Zambian government's two-level game between internal and external actors during the Third Republic see Rakner (2003: esp. 174-189). 


\section{Strong Expatriate Management and Merit Orientation of Staff}

The ZRA has been a reform project closely monitored by donors. Until 2004, the British Department for International Development (DFID) provided technical assistance worth $£ 15.8$ million to the project. ${ }^{19}$ The most prominent aspect was the provision of an expatriate management team for the ZRA. In the beginning, none of the authority's four most senior managers was Zambian. Three Commissioners, including the Commissioner General, were from the United Kingdom and one from Tanzania.

Foreign personnel was thought to be less integrated into local social networks and less responsive to Zambia's neopatrimonial environment (Kasanga 1996: 21; Delay et al. 1999: 23; Gray/Chapman 2001: 40). According to the long-serving Economic Advisor to President Chiluba, 'it was a deliberate policy to have top managers paid by DFID. It was a very important influence to de-link Commissioners from local politics' (22.4.2004, int.). Their task was to instil a new sense of professionalism in Zambia's tax administration. Only in February 2002, almost nine years after the creation of the tax agency, the expatriate Commissioner General as the last manager from abroad left and was followed by a Zambian. The donors' strategy therefore was to insulate the revenue authority from its neopatrimonial environment by bringing in foreign managers.

The ZRA's local managers maintain close connections to the political sphere (Gloppen/Rakner 2002: 34). The intimate exchange became obvious when a dismissed Commissioner of Customs directly appealed to the President and was reinstated following pressure from the Presidency (Times of Zambia 20.5.2004; Times of Zambia 25.5.2004). Although politicians do not openly interfere with the recruitment process as seems to be the case in other countries' revenue authorities (for Uganda see Therkildsen 2004: 73), a high number of ZRA employees feel that politics are involved in the appointment of senior managers. Even one member of the ZRA's Governing Board consented that 'a lot of them have access to politicians' (26.5.2004, int.). However, the ZRA has brought a significant increase in the qualification of tax administration managers. The neopatrimonial environment today exerts less influence on them than under the old dispensation.

The lack of merit orientation among low level and middle level staff had been one of the main deficits of the former tax administration Departments. In contrast, the ZRA pursues its own recruitment policy for tax officers, thereby circumventing the Public Service Commis-

19 In 1994, the responsible British Ministry was named 'Overseas Development Administration'; since 1997 it operates under the name 'Department for International Development' (DFID). The scope of the DFID intervention expanded considerably beyond a mere support of the ZRA. Since 2000, the DFID has also supported the Tax Policy Unit within Zambia's Ministry of Finance and National Planning and has assisted local NGOs to build knowledge on taxation issues. Therefore, the sum was not completely awarded to the ZRA. 
sion which is responsible for the rest of Zambia's civil service (see in general Devas et al. 2001: 214). Before the revenue authority was launched, every civil servant had to reapply in order to be employed by the new institution. The revenue authority only took over the bestqualified officers which had not been involved in corrupt activities.

Later, the management introduced minimum qualifications, meaning that every middlelevel tax officer must hold a diploma or a higher degree from university. This entrance barrier has been of crucial importance for the ZRA's merit orientation: Managers can 'hide behind $^{\prime 20}$ it and so resist the recruitment of unqualified staff due to neopatrimonial pressures. Accordingly, ZRA employees and external respondents overwhelmingly perceived the recruitment process for low and middle level tax officers to be transparent and fair. This general perception was mirrored by respondents from outside Zambia's tax administration.

Furthermore, a high-level remuneration scheme makes employment at the revenue authority very attractive. On its inception, the ZRA paid tax officers on average two- or three-fold the salary they had received in government. A middle ranking officer in 1994 earned Kwacha 49,000 per month and after 1 April 1994, the launch of the ZRA, the same employee was paid K140,000.21 Additionally, the authority provides substantial allowances and benefits. Tax officers today belong to the best-paid employees in Zambia and - together with the central bank's staff - form the administrative elite of the country.

It is one of the revenue authority's biggest achievements, that it has largely de-linked the employment of administrative staff from Zambia's neopatrimonial environment. The 75 interviews with respondents from inside and outside the ZRA provide strong indications that the merit orientation of tax officers has improved considerably. This is despite the fact that Zambia's political actors have continuously made use of neopatrimonial practices. The prime actors setting the ZRA's foundations were, however, expatriate and not local managers. In this regard, the revenue authority for a long time was an 'exterritorial' organisation.

20 This term was chosen by a former Commissioner General interviewed for this article.

21 Today, the difference in some areas is even bigger. A young graduate in the Tax Policy Unit of the Ministry of Finance and National Planning earns K890,000 per month (equivalent to roughly US\$ 190), whereas his or her counterpart in the ZRA's Executive Support Unit is paid around K7,000,000 (roughly US\$ 1500) as a monthly salary (in 2004 prices; information from ZRA). The ZRA salary for this position therefore is approximately eight times higher than in the public sector. For Tanzania, Fjeldstad (2002: 8) reports that the remuneration for some staff categories was up to ten times higher than the one from corresponding positions in the traditional public administration. 


\section{Restricted Interference with Day-to-day Business}

Despite donor surveillance and general government support, it appears that in various instances taxpayers have received preferential treatment whereas others have been harassed. ${ }^{22}$ This indicates some neopatrimonial influence on the ZRA's day-to-day business of assessing tax liabilities.

At least in the beginning, prominent MMD politicians and their businesses were not controlled through tax audits (Kasanga 1996: 23). A common phrase employees heard from their managers in these cases was 'don't go to this man, this man is difficult'. Respondents mentioned several politician-owned companies which allegedly have never paid tax. Furthermore, the ZRA was apparently told not to control 'special' government members for dutiable goods at border posts.

On the other hand, the Chiluba government used arbitrary tax auditing and fines as a means of pursuing an 'almost irrational behaviour [...] towards outspoken NGOs' (Erdmann/ Simutanyi 2003: 42). For example, in 2003 it set bailiffs on the organisation Afronet for tax evasion. Seven cars and other property were sized (Erdmann/Simutanyi 2003: 57). One prominent member of the Zambian NGO Forum for Democratic Process (FODEP) reported a similar incident. According to him, the organisation did not have any tax arrears, which makes this measure arbitrary (26.4.2004, int.). It was only following donor pressure that seized FODEP money was released.

This suggests that taxation in the Third Republic in some cases has been used for harassment of opponents or for the provision of unlawful benefits to government members. Affirmed by a former Commissioner General, he indeed sometimes reported to the British Ambassador or the local IMF Representative in order to protect the interests of the ZRA visà-vis the Zambian government. In general, however, Zambia's government has limited undue influence on the revenue authority's day-to-day business compared to its predecessor institutions. Affirmed by most respondents, even from civil society, instances of positive or negative discrimination have at least in the recent years not been of a systemic nature.

\section{Increased but Stagnating Revenue Performance}

The restriction of neopatrimonial interference has resulted in improved revenue performance. The tax-to-GDP ratio went up sharply from 15.3 to $18.7 \%$ in the first year of ZRA's operation (World Bank 2003: 15), total revenue collected increased by 61\% (Kasanga 1996: 17).

22 There was no other question on which respondents gave such disparate answers. While the ZRA management claimed that there is no political interference, some employees on the low/middle level as well as NGO representatives strongly maintained that there has been selective application of the tax code in Zambia. 
In the following years, the tax take has largely remained stagnant. This stagnation could be attributed to tax policy changes, tax exemptions and Zambia's unfavourable economic development (Gray et al. 2001: 21-23; Hill 2004: 137). The major factors depressing the tax-toGDP ratio therefore lay beyond the revenue authority's influence. Yet since 2000 Zambia's economy has grown by $4.4 \%$ on average (IMF 2005b: 55) with no increase in the tax-to-GDP ratio, indicating that the ZRA has not been able to participate in the expanding economy. This initial upward movement in revenue performance followed by stagnation or even decline has been a characteristic feature of semi-autonomous revenue authorities in Africa (Fjeldstad/Rakner 2003: 17; Gray/Chapman 2001: 26).

At least in the Zambian case, this can primarily be attributed to the small tax base the ZRA collects from. The authority has largely desisted from the administratively (and politically) demanding task of expanding direct taxation. As affirmed by a DFID-study, the ZRA's impact on direct tax collection has remained 'modest' (Gray et al. 2001: 12). Income tax collection never amounted to more than eight per cent of GDP - not even in the most recent years with comparatively strong economic growth (IMF 2006: 35). With formal sector employment accounting for less than $20 \%$ of Zambia's economically active population (Central Statistical Office 1999: 40), the burden of income tax centres on the few individuals working for registered companies and the public service. Despite the remarkable initial improvement of revenue performance, this focus on easily accessible taxpayers inherently restricts the scope for increased revenue collection in Zambia.

\section{Conclusion}

The analysis of neopatrimonialism and the collection of revenue in Zambia provides answers to two basic questions: What are neopatrimonialism's consequences for financing the African state? And, secondly, what do this study's results mean for the empirical applicability of the neopatrimonialism concept?

The three features 'concentration of political power', 'award of personal favours' and 'misuse of state resources' reveal a striking continuity of neopatrimonial practice despite Zambia's regime transition in 1991. They confirm that constitutional change affects neopatrimonialism 'very little' (Szeftel 2000: 221). However, despite this neopatrimonial stability, the semi-autonomous ZRA has brought a significant increase in revenue performance. With around $18 \%$ of GDP a larger part of state revenue today comes from domestic sources than under the old administrative structure. This changing performance indicates that there is no linear correlation between neopatrimonialism and the collection of revenue. The basic expec- 
tation that neopatrimonialism necessarily diminishes revenue of the African state is not substantiated by this study.

In other areas of the state, Zambia's political actors pursue neopatrimonial exchange relations largely unabated. Government members still seem to satisfy particularistic demands through the expenditure side of the budget. Donor reports have repeatedly criticised the lack of budget discipline and the continued misuse of state resources (World Bank 2003; World Bank 2004; see also Burnell 2001a). One example is the regular authorisation of 'supplementary appropriations' for the Ministries of Home Affairs, Defence, Foreign Affairs, Finance and Labour. Under Zambia's budget regulations, these expenses are determined by the executive, with the Ministry of Finance and National Planning having up to 15 months after the end of the fiscal year to table the supplementary appropriations bill before parliament (World Bank 2003: 28-30). This practice creates much leeway for the government to appropriate funds for particularistic use without parliamentary oversight.

The specific effects of Zambia's neopatrimonialism on the collection of domestic state revenue have changed, but neopatrimonialism has not vanished. It could even be possible that the strengthened revenue generation provides additional funds for neopatrimonial practices, i.e. have even increased them on the whole. This reasoning fits well into other literature hypothesising that 'new, relatively powerful Revenue Authorities that aid donors have been helping to establish in Africa have become major conduits for accumulating and channelling unrecorded revenues in wrong hands' (Moore/Rakner 2002: 7). The reform of the tax administration in Zambia hence appears to be a typical example of the 'partial reform syndrome' (for Africa see van de Walle 2001b: 60-63; for Zambia Rakner 2003: 168), meaning that political leaders only carry out reforms which do not hurt their vested interests.

Although it is not possible to directly infer revenue performance from the neopatrimonial profile, the three indicators used in this article allow for systematic assessment of the dominating political practice in Zambia and, in turn, the political environment the tax administration has to deal with. For moving analysis forward, the three features 'concentration of political power', 'award of personal favours', and 'misuse of state resources' can form the basis of comparatively assessing neopatrimonial practices in various African states. This would serve to systematically establish differences and commonalities of neopatrimonialism on the continent.

However, despite being an independent variable of crucial importance, the question about the effect of the 'elusive' practice of neopatrimonialism is too general and, in turn, not falsifiable (see Therkildsen for a similar argument, 2005: 48-50). It is determined by the interdependence with other variables, with donor influence being the most important in this case. The donors' strategy has been to diminish the influence of Zambia's neopatrimonial envi- 
ronment through outright political pressure and - most prominently on the administrative level - through the provision of an expatriate management team. This result contributes to the emerging consensus that variables in addition to neopatrimonialism are needed in order to adequately assess political practice and its effects in sub-Saharan Africa (Abbink 2006: 196; Therkildsen 2005: 49; Kjaer 2004: 407-408). Future empirical research applying the neopatrimonialism paradigm should take this basic caveat into account. 


\section{Bibliography}

Abbink, Jon (2006): Discomfiture of Democracy? The 2005 Election Crisis in Ethiopia and its Aftermath, in: African Affairs, 105 (419), pp. 173-199.

Afronet (2002): Nchekelako - An African Reader on Corruption in Zambia. Lusaka, Zambia: Inter-African Network for Human Rights and Development (Afronet).

Alence, Rod (2004): Political Institutions and Developmental Governance in Sub-Saharan Africa, in: Journal of Modern African Studies, 42 (2), pp. 163-187.

Basedau, Matthias (2003): Erfolgsbedingungen von Demokratie im Subsaharischen Afrika. Opladen: Leske und Budrich.

Bates, Robert H.; Collier, Paul (1993): The Politics and Economics of Policy Reform in Zambia, in: Bates, Robert H.; Krueger, Anne O. (eds.), Political and Economic Interactions in Economic Policy Reform. Cambridge, MA/Oxford: Blackwell, pp. 387-443.

Bienen, Henry; van de Walle, Nicolas (1992): A Proportional Hazard Model of Leadership Duration, in: Journal of Politics, 54 (3), pp. 685-717.

Bratton, Michael (1994): Economic Crisis and Political Realignment in Zambia, in: Widner, Jennifer A. (ed.), Economic Change and Political Liberalization in Sub-Saharan Africa. Baltimore, MD: Johns Hopkins University Press, pp. 101-128.

Bratton, Michael; van de Walle, Nicolas (1997): Democratic Experiments in Africa. Regime Transitions in Comparative Perspective. Cambridge: Cambridge University Press.

Bratton, Michael; Posner, Daniel N. (1999): A First Look at Second Elections in Africa, with Illustrations from Zambia, in: Joseph, Richard (ed.), State, Conflict and Democracy in Africa. Boulder, CO: Lynne Rienner, pp. 377-407.

Bräutigam, Deborah (2002): Building Leviathan: Revenue, State Capacity and Governance, in: IDS Bulletin, 33 (3), pp. 10-20.

Burnell, Peter (2001a): Financial Indiscipline in Zambia's Third Republic: The Role of Parliamentary Scrutiny, in: Journal of Legislative Studies, 27 (3), pp. 34-64.

Burnell, Peter (2001b): The Party System and Party Politics in Zambia: Continuities Past, Present and Future, in: African Affairs, 100 (399), pp. 239-263.

Carey, Sabine C. (2002): A Comparative Analysis of Political Parties in Kenya, Zambia and the Democratic Republic of Congo, in: Democratization, 9 (3), pp. 53-71.

Central Statistical Office (1999): Living Conditions in Zambia (1998). Lusaka: Central Statistical Office.

Chabal, Patrick; Daloz, Jean-Pascal (1999): Africa Works. Disorder as Political Instrument. Bloomington, IN: Indiana University Press.

Clapham, Christopher (1985): Third World Politics. An Introduction. London: Helm. 
Coopers \& Lybrand (1992): Establishment of the Zambia Revenue Board. Draft Final Report Vol. 1: Executive Summary. Report for the Ministry of Finance, Government of the Republic of Zambia. Lusaka: Coopers \& Lybrand Zambia.

Craig, John (2001): Putting Privatisation into Practice: the Case of Zambia Consolidated Copper Mines Limited, in: Journal of Modern African Studies, 39 (3), pp. 389-410.

DCEZ (1966): Report of the Controller of Customs and Excise for the Period 1st January, 1964, to 30th June, 1965. Lusaka: Department of Customs and Excise (DCEZ), Ministry of Finance.

DCEZ (1983): Annual Report of the Controller of Customs and Excise 1980. Lusaka: Department of Customs and Excise (DCEZ), Ministry of Finance.

Delay, Simon, et al. (1999): Reforming Revenue Administration - Lessons from Experience. A Study for the Department for International Development (DFID). London/Birmingham: Department for International Development (DFID)/Development Administration Group, School of Public Policy, University of Birmingham.

Devas, Nick, et al. (2001): Revenue Authorities: Are They the Right Vehicle for Improved Tax Administration?, in: Public Administration and Development, 21 (3), pp. 211-222.

DTZ (1969): Report of the Commissioner of Taxes for the year 1st January, 1968, to 31st December, 1968. Lusaka: Department of Taxes (DTZ), Ministry of Finance.

DTZ (1976): Report of the Commissioner of Taxes for the Year 1st April, 1972 - 31st March, 1973. Lusaka: Department of Taxes (DTZ), Ministry of Finance.

DTZ (1987): Report of the Commissioner of Taxes for the Year 1st April, 1983-31st March, 1984. Lusaka: Department of Taxes (DTZ), Ministry of Finance and National Commission for Development Planning.

EIU (2005): Country Report Zambia March 2005. London: Economist Intelligence Unit (EIU).

Electoral Commission of Zambia (2006): General Elections 2006. Presidential - National Result by Candidate. Lusaka: Electoral Commission of Zambia, in: www.elections.org.zm/ new_elections_data/totalsummary.pdf, access: 6.10.2006.

Englebert, Pierre (2000): State Legitimacy and Development in Africa. Boulder, CO: Lynne Rienner.

Erdmann, Gero; Simutanyi, Neo (2003): Transition in Zambia. The Hybridisation of the Third Republic. Lilongwe: Konrad Adenauer Foundation.

Erdmann, Gero; Engel, Ulf (2006): Neopatrimonialism Revisited - Beyond a Catch-All Concept. GIGA Working Paper No 16. Hamburg: GIGA German Institute of Global and Area Studies. 
Europa Publications (1971-2004): Africa South of the Sahara. London: Europa Publications, Taylor and Francis.

Financial Mail (27.8.-2.9.2002): There is Urgent Need to Raise Councils [sic!] Credibility. Lusaka: Financial Mail, 27.8.-2.9.2002.

Fjeldstad, Odd-Helge (2002): Fighting Fiscal Corruption: The Case of the Tanzania Revenue Authority. CMI Working Paper 3. Bergen: Chr. Michelsen Institute (CMI).

Fjeldstad, Odd-Helge; Rakner, Lise (2003): Taxation and Tax Reforms in Developing Countries: Illustrations from Sub-Saharan Africa. CMI Report 6. Bergen: Chr. Michelsen Institute (CMI).

Gill, Jit B. S. (2003): The Nuts and Bolts of Revenue Administration Reform. Washington, DC: World Bank, in: www1.worldbank.org/publicsector/pe/tax/NutsBolts.pdf, access: 10.1.2004.

Gloppen, Siri; Rakner, Lise (2002): Accountability through Tax Reform? Reflections from Sub-Saharan Africa, in: IDS Bulletin, 33 (3), pp. 30-40.

Goldsmith, Arthur A. (1999): Africa's Overgrown State Reconsidered. Bureaucracy and Economic Growth, in: World Politics, 51 (4), pp. 520-546.

Graf Lambsdorff, Johann (2005): The Methodology of the 2005 Corruption Perceptions Index. Passau: Transparency International (TI)/University of Passau, in: www.icgg.org/ downloads/CPI_Methodology.pdf, access: 10.12.2005.

Gray, John; Chapman, Emma (2001): Evaluation of Revenue Projects. Synthesis Report Vol. 1. Evaluation Report EV 636. London: Department for International Development (DFID).

Gray, John, et al. (2001): Evaluation of the Zambia Revenue Authority Consolidation Project. DFID Evaluation of Revenue Projects Vol. II. Evaluation Report EV 636. London: Department for International Development (DFID).

Hill, Catharine B. (2004): Tax Reform in Zambia, in: Hill, Catharine B.; McPherson, Malcolm F. (eds.), Promoting and Sustaining Economic Reform in Zambia. Cambridge, MA: Harvard University Press, pp. 107-144.

Hood, Christopher (1990): A Public Management for all Seasons?, in: Public Administration, 69 (1), pp. 3-19.

IMF (2005a): Zambia: Enhanced Initiative for Heavily Indebted Poor Countries - Completion Point Document. IMF Country Report 05/137. Washington, DC: International Monetary Fund (IMF).

IMF (2005b): Regional Economic Outlook Sub-Saharan Africa May 2005. Washington, DC: International Monetary Fund (IMF). 
IMF (2006): Zambia: 2005 Article IV Consultation, Third Review Under the Three-Year Arrangement Under the Poverty Reduction and Growth Facility. IMF Country Report 06/39. Washington, DC: International Monetary Fund (IMF).

Internet Center for Corruption Research (2005): Transparency International (TI) Corruption Perceptions Index, 1998-2005. Passau: University of Passau/Transparency International, in: www.icgg.org/corruption.cpi_2005.html, access: 6.12.2005.

Kasanga, John M. (1996): Study of 'Enclave' Approach to Tax and Customs Administration in Zambia. Lusaka: World Bank Zambia.

Kaufmann, Daniel, et al. (2005a): Governance Matters IV: Governance Indicators for 19962004. Washington, DC: World Bank.

Kaufmann, Daniel, et al. (2005b): Governance Research Indicator Country Snapshot (GRICS): 1996-2004. Washington, DC: World Bank, in: http://info.worldbank.org/governance/kkz 2004/, access: 24.3.2006.

Kaunda, Kenneth (1972): The Leadership Code and Responsibilities of the Leadership in the Creation of a New Social Order. Address to the National Council on 2nd December, 1972. Lusaka: Government of Zambia.

Kjaer, Anne Mette (2004): 'Old Brooms Can Sweep Too!' An Overview of Rulers and Public Sector Reforms in Uganda, Tanzania and Kenya, in: Journal of Modern African Studies, 42 (3), pp. 389-413.

Macmillan (1964-1970): The Statesman's Year-Book. London: Macmillan.

Manow, Philip (2002): Was erklärt Politische Patronage in den Ländern Westeuropas? Defizite des politischen Wettbewerbs oder historisch-formative Phasen der Massendemokratisierung, in: Politische Vierteljahresschrift, 43 (1), pp. 20-45.

McPherson, Malcolm F. (2004a): The Historical Context, in: Hill, Catharine B.; McPherson, Malcolm F. (eds.), Promoting and Sustaining Economic Reform in Zambia. Cambridge, MA: Harvard University Press, pp. 29-48.

McPherson, Malcolm F. (2004b): Ending Aid Dependence in Zambia, in: Hill, Catharine B.; McPherson, Malcolm F. (eds.), Promoting and Sustaining Economic Reform in Zambia. Cambridge, MA: Harvard University Press, pp. 445-478.

Médard, Jean-François (1982): The Underdeveloped State in Tropical Africa: Political Clientelism or Neo-Patrimonialism?, in: Clapham, Christopher (ed.), Private Patronage and Public Power. Political Clientelism in the Modern State. New York: St. Martin's Press, pp. 162-192.

Moore, Mick; Rakner, Lise (2002): Introduction: The New Politics of Taxation and Accountability in Developing Countries, in: IDS Bulletin, 33 (3), pp. 1-9. 
OECD (2004): Public Sector Modernisation: Changing Organisational Structures. OECD Policy Brief/OECD Observer, Public Sector Modernisation 3. Paris: Organisation for Economic Co-operation and Development (OECD).

Olowu, Dele (2003): African Governance and Civil Service Reforms, in: van de Walle, Nicolas, et al. (eds.), Beyond Structural Adjustment: The Institutional Context of African Development. Houndmills: Palgrave Macmillan, pp. 101-130.

Posner, Daniel N.; Simon, David J. (2002): Economic Conditions and Incumbent Support in Africa's New Democracies: Evidence from Zambia, in: Comparative Political Studies, 35 (3), pp. 313-336.

Rakner, Lise (2003): Political and Economic Liberalisation in Zambia 1991-2001. Uppsala: Nordic Africa Institute.

Rakner, Lise; Svåsand, Lars (2005): Stuck in Transition: Electoral Processes in Zambia 19912001, in: Democratization, 12 (1), pp. 85-105.

Republic of Zambia (1992): Budget Address. Delivered on 31.1.1992. Lusaka: Ministry of Finance, Government of the Republic of Zambia.

Republic of Zambia (1996): Zambia Revenue Authority Amendment Act, Act 32 of 1996. Lusaka: Republic of Zambia.

Republic of Zambia (2004): Constitution of the Republic of Zambia. Lusaka: Republic of Zambia.

Republic of Zambia (2005): Composition of Government as at 3rd August, 2005. Government Document. Lusaka: Office of the President, Government of the Republic of Zambia.

Rose-Ackerman, Susan (2004): The Challenge of Poor Governance and Corruption. Copenhagen: Copenhagen Consensus, Environmental Assessment Institute, in: www.imv.dk/ Files/Filer/CC/Papers/Governance_and_Corruption_300404_(6.4MB_version).pdf, access: 30.11.2005.

Routledge (2005): Africa South of the Sahara. London: Routledge.

Scott, Ian (1980): Party and Administration under the One-Party State, in: Tordoff, William (ed.), Administration in Zambia. Manchester: Manchester University Press, pp. 139-161.

Silvani, Carlos; Baer, Katherine (1997): Designing a Tax Administration Reform Strategy: Experiences and Guidelines. IMF Working Paper 30. Washington, DC: International Monetary Fund (IMF).

Simon, David J. (2005): Democracy Unrealized. Zambia's Third Republic under Frederick Chiluba, in: Villalón, Leonardo A.; VonDoepp, Peter (eds.), The Fate of Africa's Democratic Experiments. Elites and Institutions. Bloomington, IN: Indiana University Press, pp. 199-220. 
Snyder, Richard (1992): Explaining Transitions from Neopatrimonial Dictatorships, in: Comparative Politics, 24 (4), pp. 379-400.

Snyder, Richard; Mahoney, James (1999): The Missing Variable. Institutions and the Study of Regime Change, in: Comparative Politics, 32 (1), pp. 103-122.

Szeftel, Morris (1982): Political Graft and the Spoils System in Zambia - the State as a Resource in Itself, in: Review of African Political Economy (24), pp. 4-21.

Szeftel, Morris (2000): 'Eat with Us': Managing Corruption and Patronage Under Zambia's Three Republics, 1964-99, in: Journal of Contemporary African Studies, 18 (2), pp. 207-224.

Tax Policy Task Force (1992): Final Report Presented to the Minister of Finance, Hon. E.G. Kasonde. Recommendations on Tax Reform for the 1993 Budget. Lusaka: Tax Policy Task Force, Ministry of Finance, Budget Section.

The Post (3.1.2006): 2005 was a very Successful Year. Lusaka: The Post, 3.1.2006.

The Post (20.4.2004): Levy's Failure to Cut Size of Cabinet Unfortunate - Nonde. Lusaka: The Post, 20.4.2004.

The Post (26.4.2004): Deputy Ministers. Lusaka: The Post, 26.4.2004.

Therkildsen, Ole (2004): Autonomous Tax Administration in Sub-Saharan Africa: the Case of the Uganda Revenue Authority, in: Forum for Development Studies, 31 (1), pp. 59-88.

Therkildsen, Ole (2005): Understanding Public Management through Neopatrimonialism: A Paradigm for all African Seasons?, in: Engel, Ulf; Olsen, Gorm Rye (eds.), The African Exception. London: Ashgate, pp. 33-51.

Times of Zambia (20.5.2004): ZRA Commissioner Relieved of His Duties. Lusaka: Times of Zambia, 20.5.2004.

Times of Zambia (25.5.2004): ZRA Extends Tax Evasion Probes. Lusaka: Times of Zambia, 25.5.2004.

TIZ (2002): 2002 State of Corruption Report. Lusaka: Transparency International Zambia (TIZ).

TIZ (2003): Report on Developing a System of Tracking and Documenting Abuse of Public Funds in Zambia. Lusaka: Transparency International Zambia (TIZ).

Tordoff, William; Molteno, Roberto (1974): Government and Administration, in: Tordoff, William (ed.), Politics in Zambia. Manchester: Manchester University Press, pp. 242-287. van de Walle, Nicolas (2001a): The Impact of Multi-Party Politics in Sub-Saharan Africa, in: Forum for Development Studies, 28 (1), pp. 5-42.

van de Walle, Nicolas (2001b): African Economies and the Politics of Permanent Crisis, 19791999. Cambridge: Cambridge University Press. 
van de Walle, Nicolas (2005): The Donors and the State in Africa: How Much Has Changed?, in: Engel, Ulf; Olsen, Gorm Rye (eds.), The African Exception. London: Ashgate, pp. 69-84. van Donge, Jan Kees (1995): Zambia: Kaunda and Chiluba. Enduring Patterns of Political Culture, in: Wiseman, John A. (ed.), Democracy and Political Change in Sub-Saharan Africa. London: Routledge, pp. 193-219.

Weber, Max (1980 [1922]): Wirtschaft und Gesellschaft. Grundriß der verstehenden Soziologie. Tübingen: J.C.B. Mohr.

World Bank (2002): World Development Report 2002. Building Institutions for Markets. Oxford: Oxford University Press.

World Bank (2003): Zambia - Public Expenditure Management and Financial Accountability Review. Report No. 26162-ZA. Washington, DC: World Bank.

World Bank (2004): Memorandum of the President of the International Development Association to the Executive Directors on a Country Assistance Strategy for the Republic of Zambia ['Country Assistance Strategy']. Report No. 27654-ZA. Washington, DC: World Bank.

World Bank (2005): World Bank Africa Database 2005 on CD-ROM. Washington, DC: World Bank.

Young, Crawford: (1994): The African Colonial State in Comparative Perspective. New Haven, CT: Yale University Press.

\section{Newspapers (Published in Lusaka)}

Financial Mail, The Post, Times of Zambia, Zambia Daily Mail

\section{Interviews}

In order to protect the respondents cited in this article, their names were made anonymous. A list of all respondents and the transcripts of the interviews are filed on CD ROM and can be obtained from the author on request.

Former Tax Officer with the Department of Taxes and ZRA, respectively (1969 to 2003), Lusaka, 14.4.2004.

Former Economic Advisor to President Chiluba, Lusaka, 22.4.2004.

Former representative, Forum for Democratic Process (FODEP), Lusaka, 26.4.2004.

Member of the ZRA Governing Board, Lusaka, 26.5.2004. 


\section{G

\section{Recent issues:}

No 31 Susan Steiner: Decentralisation in Uganda: Exploring the Constraints for Poverty Reduction; November 2006

No 30 Detlef Nolte: Potencias regionales en la política internacional: conceptos y enfoques de análisis [Regional Powers in International Relations: Analytical Concepts and Research Approaches]; October 2006

No 29 Detlef Nolte: Macht und Machthierarchien in den internationalen Beziehungen: Ein Analysekonzept für die Forschung über regionale Führungsmächte [Power and Power Hierarchies in International Relations: Towards an Analytical Concept for the Study of Regional Powers]; October 2006

No 28 Bert Hoffmann and Laurence Whitehead: Cuban Exceptionalism Revisited; September 2006

No 27 Andreas Mehler: Political Discourse in Football Coverage - The Cases of Côte d'Ivoire and Ghana; August 2006

No 26 Martin Beck: Probleme des Rentierstaats-Ansatzes in vergleichender Perspektive [Problems of the Rentier State Approach in Comparative Perspective]; August 2006

No 25 Dirk Kohnert: Cultures of Innovation of the African Poor. Common Roots, Shared Traits, Joint Prospects? On the Articulation of Multiple Modernities in African Societies and Black Diasporas in Latin America; July 2006

No 24 Jan Peter Wogart: Multiple Interfaces of Big Pharma and the Change of Global Health Governance in the Face of HIV/AIDS; June 2006

No 23 Daniel Flemes: Brazil's Nuclear Policy. From Technological Dependence to Civil Nuclear Power; June 2006

No 22 Leany Barreiro Lemos and Mariana Llanos: The Politics of Senatorial Confirmations: A Comparative Study of Argentina and Brazil; May 2006

No 21 Matthias Basedau and Wolfram Lacher: A Paradox of Plenty? Rent Distribution and Political Stability in Oil States; April 2006

No 20 Esther K. Ishengoma and Robert Kappel: Economic Growth and Poverty: Does Formalisation of Informal Enterprises Matter?; April 2006

No 19 Anika Oettler: Guatemala in the 1980s: A Genocide Turned into Ethnocide?; March 2006

No 18 Heike Holbig: Ideological Reform and Political Legitimacy in China: Challenges in the Post-Jiang Era; March 2006

No 17 Howard Loewen: Towards a Dynamic Model of the Interplay Between International Institutions; February 2006

All GIGA Working Papers are available free of charge at www.giga-hamburg.de/workingpapers. For any requests please contact: workingpapers@giga-hamburg.de.

Editor of the Working Paper Series: Bert Hoffmann. 